\title{
Multimedia Interaktif Sebagai Media Informasi Mengenai Pengenalan Energi Alternatif
}

\author{
Jaenal Arifin', M. Rizky Fadhlillah² \\ ${ }^{1,2}$ Teknik Informatika, STMIK Asia Malang \\ 1jaenalarifin@asia. ac. id, ${ }^{2}$ rzkylah@gmail.com
}

\begin{abstract}
ABSTRAK
Energi alternatif merupakan alternatif sumber daya alam yang digunakan untuk berbagai macam keperluan sehari-hari di Indonesia, informasi mengenai energi alternatif sangat minim sekali karena belum banyak sarana atau media yang membahasnya sehingga pelajar maupun masyarakat luas belum mengetahui apa energi alternatif serta manfaatnya. Oleh karena itu penggunaan multimedia interaktif merupakan solusi yang dapat mengatasi masalah kurangnya informasi tersebut. Tujuan dari pembuatan multimedia interaktif ini adalah untuk memberikan informasi dan pengenalan seputar energi alternatif khususnya yang sudah dikembangkan karena energi alternatif jumlahnya terus bertambah dikarenakan banyak inovasi dari pengembangan energi alternatif yang sudah ada. Selain bersifat interaktif, media ini juga berisi penjelasan mengenai perkembangan energi alternatif untuk masa depan agar media ini tidak menjadi media yang ketinggalan zaman dan dapat berfungsi sebagai alat untuk memberikan edukasi mengenai pemanfaatan energi alternatif. Kesimpulan dari penelitian yang dilakukan berdasarkan permasalahan yang telah diselesaikan dengan pembuatan multimedia interaktif dapat dikatakan baik dan membuat user tertarik untuk menggunakannya sebagai sarana pengenalan energi alternatif dan pengembangannya.
\end{abstract}

Kata Kunci: Multimedia; Interaktif; Energi Alternatif; Media Informasi; Edukasi

\begin{abstract}
Alternative energy is an alternative natural resource that is used for various daily necessities in Indonesia, the information about alternative energy is very minimal because not many facilities or media that discuss it so that students and the general public do not know what alternative energy and its benefits. Therefore the use of interactive multimedia is a solution that can solve the problem of lack of such information. The purpose of making interactive multimedia is to provide information and introduction about alternative energy especially those that have been developed because of alternative energy numbers continue to grow due to many innovations from the development of alternative energy that already exists. In addition to being interactive, the media also contains an explanation of the development of alternative energy for the future so that this media does not become an outdated medium and can serve as a tool to educate about the utilization of alternative energy. The conclusion of the research conducted based on the problems that have been solved by making interactive multimedia can be said to be good and make the user interested to use it as a means of introduction of alternative energy and its development.
\end{abstract}

Keywords: Multimedia; Interactive; Alternative Energy; Media Information; Education

\section{PENDAHULUAN}

Energi merupakan sebuah kekuatan yang berguna sebagai penunjang aktifitas semua makhluk hidup khususnya manusia dalam beraktifitas sehingga peran energi sangat penting bagi manusia akan tetapi akhir-akhir ini energi tersebut semakin menipis disebabkan sumber energi yang digunakan tidak bisa diperbarui. Karena kurangnya kesadaran masyarakat mengenai energi yang terbarukan atau alternatif hal ini dapat menimbulkan perubahan suhu yang ekstrim yang dikenal dengan istilah pemanasan global. Agar masyarakat sadar dan memiliki keinginan untuk menggunakan energi alternatif, diperlukan sosialisasi mengenai penggunaan energi alternatif.

Dengan menggunakan media yang dapat menyampaikan informasi secara interaktif, dengan pembuatan multi media interaktif sebagai media informasi pengenalan energi 
alternatif, diharapkan masyarakat akan lebih mudah dan cepat memahami informasi yang diberikan.

Media informasi menggunakan multimedia interaktif yang akan dirancang dalam penelitian ini bertujuan untukmemperkenalan energi alternatif yang terbarukan sebagai pengganti energi tak terbarukan yang digunakan saat ini dan juga memberikan informasi serta menambah pengetahuan mengenai jenis, fungsi dan manfaat energi alternatifserta meningkatkan kesadaran akan menipisnya cadangan energi tak terbarukan akibat eksplorasi yang berlebihan.

Multimedia adalah sesuatu yang digunakan untuk menyampaikan atau memperlihatkan sesuatu. Multimedia dimanfaatkan dalam dunia pendidikan dan bisnis. Di dunia pendidikan, multimedia digunakan sebagai media pengajaran/pembelajaran, baik dalam kelas maupun secara sendiri-sendiri. Di dunia bisnis, multimedia digunakan sebagai media profil perusahaan, profil produk, bahkan sebagai media kios informasi dan pelatihan dalam sistem e-learning. Multimedia biasanya direkam, diputar, ditampilkan atau diakses oleh perangkat pengolahan informasi konten, seperti komputerisasi dan perangkat elektronik, tetapi juga dapat menjadi bagian dari live performance. Industri kreatif menggunakan multimedia untuk berbagai tujuan mulai dari seni, untuk hiburan, seni komersial, untuk jurnalisme, media dan layanan perangkat lunak yang disediakan untuk setiap industri.

Multimedia interaktif adalah jenis multimedia yang bisa melakukan interaksi manusia terhadap komputer dalam penyajian kumpulan teks yang bervariasi, penggabungan audio, penambahan animasi gambar, Grafik, pemutaran video yang dipermudah penggunaanya melalui alat bantu dan koneksi yang dapat melakukan navigasi, interaksi, karya, dan komunikasi (Binanto, 2010). Penggunaan multimedia sangat erat dibidang informatika, game, pembuatan website, hingga digunakaan untuk mempercantik presentasi didalam dunia bisnis ataupun pendidikan.

Pemanfaatan multimedia sangat banyak diantaranya untuk: media pembelajaran, game, film, medis, militer, bisnis, desain, arsitektur, olahraga, hobi, iklan atau promosi. Jika pengguna mendapatkan keleluasaan dalam mengontrol multimedia tersebut, maka hal ini disebut multimedia interaktif. Menurut (Binanto, 2010) di dalam multimedia interaktif ada beberapa komponen penting yang harus ada dan komponen-komponen inilah yang membentuk pondasi dasar dari sebuah multimedia interaktif. Komponen-komponen yang membentuk sebuah multimedia interaktif yaitu:

1. Teks

Teks adalah simbol berupa medium visual yang digunakan untuk menjelaskan bahasa lisan. Teks memiliki berbagai macam jenis bentuk atau tipe ukuran dan warna. Satuan dari ukuran suatu teks terdiri dari length dan size. Length biasanyamenyatakan banyaknya teks dalam sebuah kata. Size menyatakan ukuran besar atau kecil suatu huruf.

2. Grafik

Grafik adalah suatu medium berbasis visual. Seluruh gambar dua dimensi adalah grafik. Apabila gambar dirender dalam bentuk tiga dimensi (3D), maka tetap disajikan melalui medium dua dimensi. Hal ini termasuk gambar yang disajikan lewat kertas, televisi ataupun layar monitor. Grafik bisa saja menyajikan kenyataan (reality) seperti foto atau hanya berbentuk iconic seperti kartun. Grafik terdiri dari gambar diam (foto, gambar digital, lukisan, dan poster ) dan gambar bergerak (animasi, video dan film).

3. Image

Secara umum image berarti gambar atau raster (halfonedrawing), seperti foto. Foto-foto seperti gedung dan lain-lain sangat memerlukan penyimpanan yang besar. Hal inilah 
yang menyebabkan aplikasi multimedia disimpan dalam penyimpanan yang cukup besar kapasitasnya seperti CD-Room.

4. Animasi

Animasi berarti gerakan image atau video, contohnya gerakan orang yang melakukan suatu kegiatan. Konsep dari animasi adalah sulitnya menggambarkan informasi dengan satu gambar saja, atau sekumpulan gambar, juga tidak dapat menggunakan teks untuk menerangkan informasi.

5. Audio

Audio dapat lebih memperjelas pengertian yang ditampilkan dalam teks dan video. Contohnya, narasi merupakan kelengkapan dari penjelasan yang dilihat melalui video. Suara dapat memberikan lebih menjelaskan karakteristik suatu gambar, misalnya musik dan suara efek (sound effect).

6. Interaktive Link

Sebagian dari multimedia adalah interaktif, dimana pengguna dapat menekan mouse atau objek pada screen seperti button atau teks dan menyebabkan program melakukan perintah tertentu. Interaktif link diperlukan jika pengguna, menunjuk pada suatu objek atau button agar dapat mengakses program tertentu. Interaktif link diperlukan untuk menggabungkan beberapa elemen multimedia sehingga menjadi informasi yang terpadu. Cara pengaksesan informasi pada multimedia terdapat dua macam yaitu linier dan non-linier. Informasi linier adalah informasi yang ditampilkan secara sekuensial, yaitu dari atas ke bawah atau halaman demi halaman. Sedangkan pada informasi non-linier informasi dapat ditampilkan langsung sesuai dengan kehendak pengguna.

Saat ini kebutuhan akan energi terbarukan atau dikenal dengan istilah energi alternatif semakin lama semakin meningkat disebabkan karena energi yang digunakan saat ini jumlahnya semakin menipis dan tidak bisa diperbarui (Nugroho, 2012). Di Indonesia energi alternatif mulai dikembangkan oleh beberapa pihak terutama dari kalangan masyarakat dan akademisi sebagai solusi untuk mengatasi kelangkaan sumber daya energi, namun pemerintah Indonesia sendiri belum menaruh perhatian besar pada pengembangan energi alternatif. Sejauh ini pengembangan dan penggunaan energi alternatif hanya dilakukan oleh beberapa orang saja dan belum bersifat massal. Jenis energi alternatif yang sudah dikembangkan dan digunakan adalah sebagai berikut:

1. Energi Matahari

Matahari merupakan sumber energi yang tak habis-habisnya. Kehidupan di dunia ini hampir sepenuhnya berkat energi matahari, karena makanan itu sebenarnya energinya berasal dari matahari yang tersimpan dalam tumbuhan maupun hewan. Selain itu, berbagai jenis energi baik yang terbarukan maupun tak-terbarukan merupakan bentuk turunan dari energi matahari, baik secara langsung maupun tidak langsung. Pemanfaatan energi panas matahari sebenarnya telah dilakukan diantaranya yaitu: Penerangan Ruangan, Kompor Matahari, Pemanasan air, Pembangkitan listrik.

2. Energi Panas Bumi

Energi geothermal atau energi panas bumi adalah energi yang berasal dari inti bumi. Inti bumi merupakan bahan yang terdiri atas berbagai jenis logam dan batu yang berbentuk cair, yang memiliki suhu tinggi. Energi ini dapat digunakan untuk menghasilkan listrik sebagai salah satu bentuk dari energi terbaharui, tetapi karena panas di suatu lokasi dapat habis, jadi secara teknis dia tidak diperbarui secara mutlak. Energi geothermal yang dapat dimanfaatkan sekarang ini adalah panas bumi yang berasal dari magma. Magma adalah batuan cair/panas bumi yang terdapat di dalam/kerak bumi. Selanjutnya, apabila dilakukan pengeboran, maka akan terjadi semburan yang berupa gas/uap air panas atau air panas, bila semburan itu mengeluarkan uap air panas, sehingga dapat 
langsung dimanfaatkan untuk memutar turbin uap yang kemudian dikaitkan dengan generator pembangkit listrik dan akan diperoleh energi listrik.

3. Energi Angin

Penggerakan udara itu disebabkan oleh perbedaan suhu. Perbedaan suhu disebabkan oleh perbedaan daya serap panas di permukaan bumi. Jadi, selama matahari masih memancarkan sinarnya ke bumi dan di bumi terdapat daratan dan lautan, maka akan terjadi perbedaan suhu dan menyebabkan terjadinya angin. Pemanfaatan teknologi energi angin sebagai salah satu sumber energi yang dapat diperbarui juga sudah dilakukan di Indonesia. Tetapi energi listrik yang dihasilkan dari angin masih relatif kecil kapasitasnya. Sehingga umumnya teknologi ini hanya diterapkan di daerah terpencil atau di pedesaan yang belum terjangkau aliran listrik PLN.

4. Energi Laut

Laut memiliki potensi yang besar, yaitu ikan, tanaman laut, harta karun, dan masih banyak lagi. Prinsip sederhana dari pemanfaatan bentuk energi laut adalah memakai energi kinetik untuk memutar turbin yang selanjutnya menggerakkan generator untuk menghasilkan listrik. Energi yang berasal dari laut (ocean energy) dapat dikatagorikan menjadi dua macam, yaitu: Energi Ombak (Wave Energy), Surut (Tidal Energy/Energi Pasang)

5. Energi Biogas

Biogas merupakan gas campuran metana $(\mathrm{CH} 4)$, karbondioksida $(\mathrm{CO} 2)$ dan gas lainnya yang didapat dari hasil penguraian material organik seperti kotoran hewan, kotoran manusia, dan tumbuhan oleh bakteri pengurai metanogen pada sebuah biodigester. Bahan dasar biogas adalah sisa-sisa jasad hidup, misalnya sampah pertanian seperti batang pohon jagung, jerami, sisa ampas kelapa, enceng gondok, akasia, dan sebagainya yang dicampur dengan bahan yang mengandung bakteri pengurai misalnya kotoran kerbau atau sapi. Prosesnya harus dilakukan dalam keadaan tertutup rapat dan tidak boleh kemasukan udara. Setelah jadi biogas kemudian ditampung dalam tangki penampungan gas dan dapat dialirkan ke rumah untuk memasak, untuk pabrik tahu, atau untuk keperluan lain.

6. Energi Biofuel

Bahan bakar hayati atau biofuel adalah setiap bahan bakar baik padatan, cairan ataupun gas yang dihasilkan dari bahan-bahan organik. Biofuel dapat dihasilkan secara langsung dari tanaman atau secara tidak langsung dari limbah industri, komersial, domestik atau pertanian. Ada tiga cara untuk pembuatan biofuel: pembakaran limbah organik kering (seperti buangan rumah tangga, limbah industri dan pertanian); fermentasi limbah basah (seperti kotoran hewan) tanpa oksigen untuk menghasilkan biogas (mengandung hingga 60 persen metana), atau fermentasi tebu atau jagung untuk menghasilkan alkohol dan ester; dan energi dari hutan (menghasilkan kayu dari tanaman yang cepat tumbuh sebagai bahan bakar). . Penggunaan biofuel mengurangi pula ketergantungan pada minyak bumi serta meningkatkan keamanan energi. Energi biofuel dapat dikategorikan menjadi dua macam yaitu:

a. Energi Bioetanol

Bioetanol telah digunakan manusia sejak zaman prasejarah sebagai bahan pemabuk dalam minuman beralkohol. . Campuran dari bioetanol yang mendekati kemrunian untuk pertama kali ditemukan oleh Kimiawan Muslim yang mengembangkan. Saat ini Bioetanol dipakai secara luas di Brazil dan Amerika Serikat. Semua kendaraan bermotor di Brazil, saat ini menggunakan bahan bakar yang mengandung paling sedikit kadar ethanol sebesar $20 \%$. Pertengahan 1980, lebih dari $90 \%$ dari mobil baru, dirancang untuk memakai bioetanol murni. Namun penggunaan bioetanol 
sebagai bahan bakar nabati kurang ditanggapi pada waktu tersebut, karena keberadaan bahan bakar minyak yang murah dan melimpah. Saat ini pasokan bahan bakar minyak semakin menyusut ditambah lagi dengan harga minyak dunia yang melambung membuat biotanol semakin diperhitungkan. Dan dengan meningkatnya harga minyak bumi, bioetanol kembali mendapatkan perhatian dan telah menjadi alternatif energi yang terus dikembangkan.

b. Energi Biodiesel

Secara sederhana biodiesel didefinisikan sebagai bentuk bahan bakar diesel yang menyebabkan lebih sedikit kerusakan lingkungan dibandingkan bahan bakar diesel standar. Biodiesel biasanya dibuat dari minyak nabati melalui proses kimia yang disebut transesterifikasi. Semua kendaraan keluaran baru dapat menggunakan biodiesel. Dalam kebanyakan kasus biodiesel tidak digunakan dalam bentuk murni (B100) melainkan dicampur dengan diesel standar. Hal ini terutama karena diesel standar lebih baik daripada biodiesel murni saat berurusan dengan suhu rendah dan juga diduga memiliki dampak yang lebih baik pada daya tahan mesin. Menggunakan biodiesel sebagai pengganti diesel standar tidak hanya akan membantu lingkungan, tetapi juga akan membantu meningkatkan kemandirian energi dan keamanan energi negara. Kelemahan dari penggunaan biodiesel lebih karena biodiesel sebagian besar masih diproduksi dari tanaman pangan yang dalam skenario terburuk menyebabkan peningkatan harga pangan dan bahkan meningkatkan kelaparan di dunia. Inilah alasan utama mengapa para ilmuwan melihat berbagai bahan baku biodiesel potensial lainnya, contohnya adalah rumput dan alga.

\section{PEMBAHASAN}

Sebelum masuk ke proses pembuatan multimedia interaktif, konsep perancangan sangat dibutuhkan untuk merencanakan alur multimedia interaktif. Hal ini dijadikan sebagai acuan untuk proses pengerjaannya, sehingga dalam proses pengerjaan lebih terarah dan jelas terutama dalam hal navigasi menu dan beberapa tombol navigasi, diagram alur memudahkan penulis untuk merencanakan komponen - komponen yang harus ada dalam multimedia interaktif ini sehingga pembuatan media ini menjadi jelas di dalam diagram alur ini. Berikut ini adalah gambar diagram alurnya.

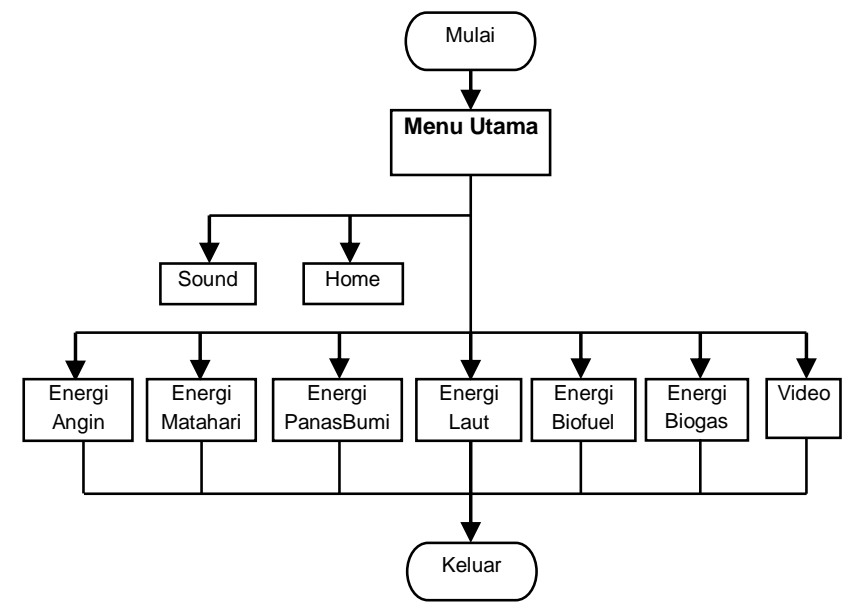

Gambar 1. Diagram Alur 
Pembuatan multimedia interaktif ini lebih ditekankan pada pengenalan energi alternatif, untuk itu pada bagian background penulis memilih menampilkan gabungan foto mengenai alat - alat pengolah energi alternatif sebagai gambaran dari energi alternatif.

Warna yang digunakan pada background adalah warna hijau untuk memberi kesan bahwa energi alternatif adalah energi yang berasal dari alam sedangkan warna di dalam menu yang berisi informasi energi alternatif merupakan warna yang penulis anggap dapat mewakili masing - masing jenis energi alternatif yang dibahas, hal ini dimaksudkan agar multimedia interaktif ini tidak terkesan monoton dengan warna hijau.

Bentuk tombol mulai pada halaman utama dibuat menyerupai lambang sistem daur ulang yang merupakan kelebihan yang dimiliki oleh semua energi alternatif sedangkan tombol pada bagian menu utama dilambangkan dengan ilustrasi yang identik dengan jenis energi alternatif.

Pada layout di tampilan awal terdiri dari background berupa kumpulan foto alat pengolah energi alternatif yang ditumpuk dengan kotak hijau sebagai tempat untuk tombol mulai dan kalimat ajakan mengenal energi alternatif. Berikut ini gambar layout tampilan awal

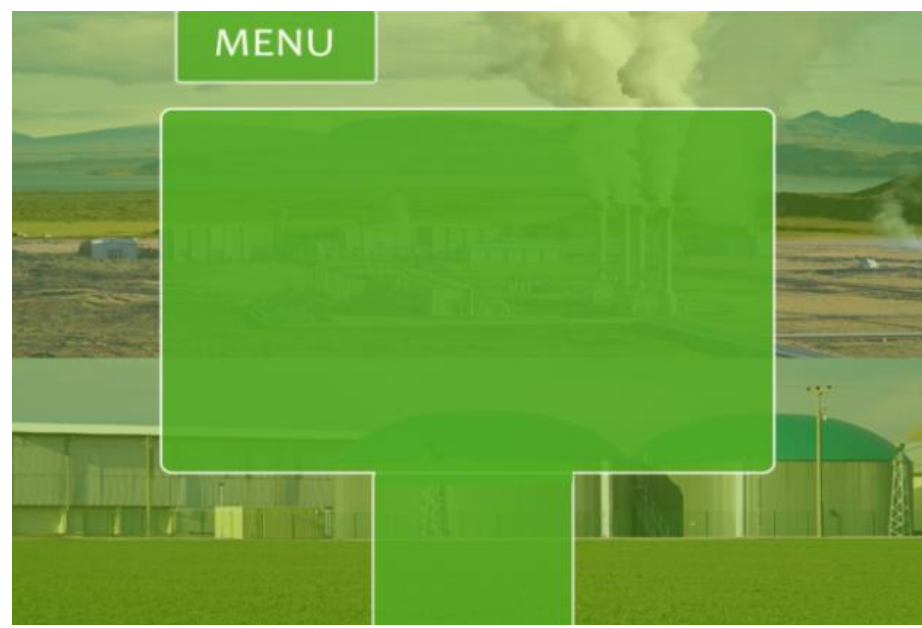

Gambar 2. Layout Menu Utama

Pada menu video layout tersusun atas dua bagian yang berukuran besar dan kecil berbentuk kotak untuk kotak pertama pertama digunakan sebagai tombol untuk memilih video sedangkan kotak kedua sebagai tempat video diletakkan. Berikut ini gambar pembuatan layout menu video.

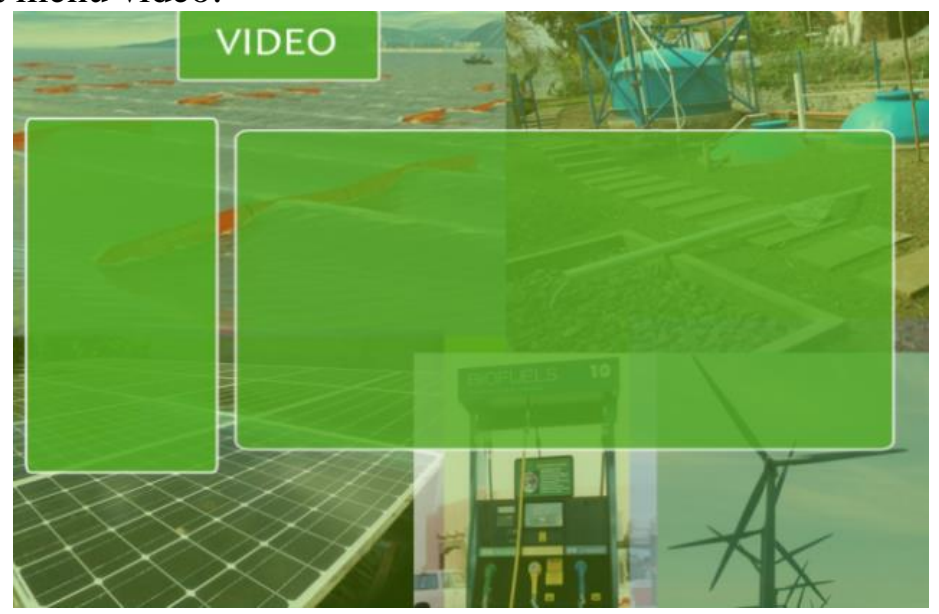

Gambar 3. Layout Menu Video 
Untuk layout di dalam menu energi angin dan matahari terdapat kotak-kotak sebagai tempat gambar informasi mengenai energi alternatif yang dibahas. Berikut ini gambar layout menu energi angin dan matahari.
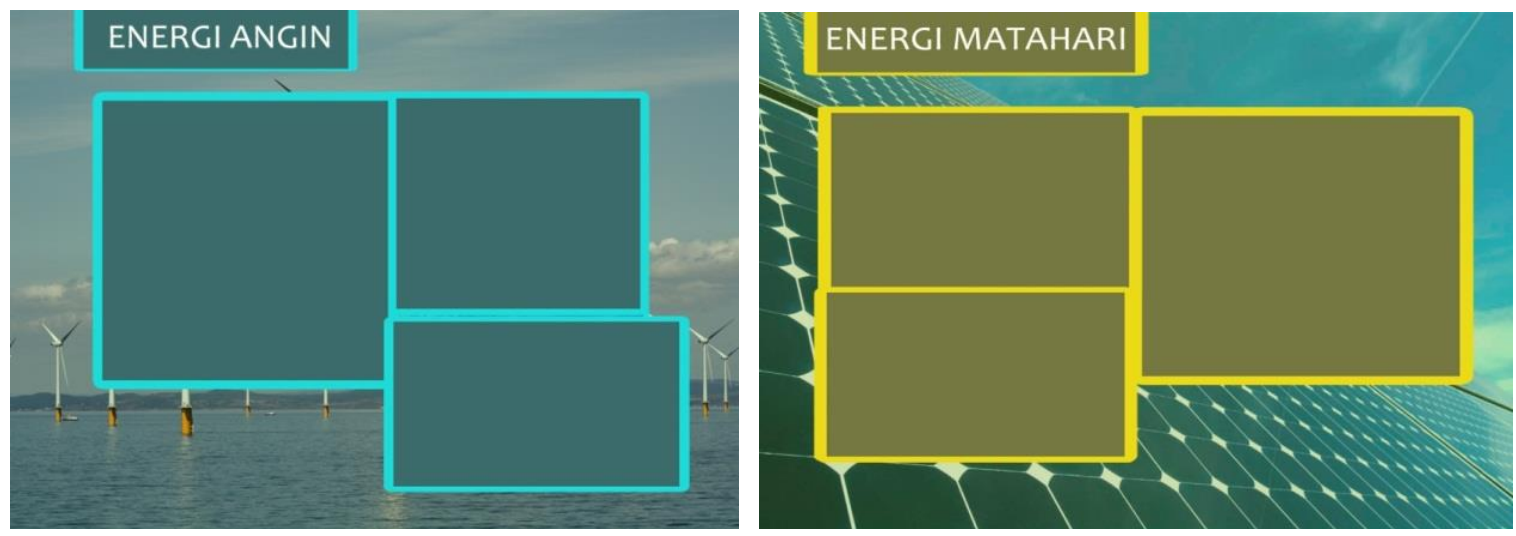

Gambar 4. Layout Menu Energi Angin dan Matahari

Pembuatan tombol navigasi difungsikan sebagai sarana interaktif dengan pengguna, sehingga pengguna dapat menentukan atau menjalankan multimedia interaktif pengenalan energi alternatif dengan mudah. Berikut tombol-tombol navigasi yang digunakan pada multimedia interaktif pengenalan energi alternatif ditampilkan dalam Tabel 1.

Tabel 1. Tombol Navigasi

\begin{tabular}{|l|l|l|l|}
\hline No & \multicolumn{1}{|c|}{ Gambar } & Nama Tombol & \multicolumn{1}{c|}{ Keterangan } \\
\hline 1 & & Home & $\begin{array}{l}\text { Tombol ini berfungsi untuk } \\
\text { kembali ke halaman utama, } \\
\text { sehingga tombol ini hanya } \\
\text { diletakkan pada halaman-halaman } \\
\text { isi atau tidak diletakkan di halaman } \\
\text { utama. }\end{array}$ \\
\hline 2 & Sound & $\begin{array}{l}\text { Tombol ini difungsikan untuk } \\
\text { pengaturan volume suara narasi } \\
\text { maupun backsound musicagar } \\
\text { volume dapat dengan mudah } \\
\text { disesuaikan dengan kebutuhan } \\
\text { dalam penggunaan musik. }\end{array}$ \\
\hline 3 & Exit & $\begin{array}{l}\text { Tombol ini berfungsi untuk } \\
\text { mempercepat keluar atau } \\
\text { menghentikan multimedia jika } \\
\text { penggunaannya sudah selesai. }\end{array}$ \\
\hline
\end{tabular}




\begin{tabular}{|l|l|l|l|}
\hline No & \multicolumn{1}{|c|}{ Gambar } & Nama Tombol & \multicolumn{1}{c|}{ Keterangan } \\
\hline 4 & & Mulai & $\begin{array}{l}\text { Tombol mulai ini digunakan untuk } \\
\text { akses masuk ke halaman main } \\
\text { menu, tombol ini menjadi tombol } \\
\text { pembuka dalam aplikasi } \\
\text { multimedia interaktif ini. }\end{array}$ \\
\hline 5 & & Video & $\begin{array}{l}\text { Tombol ini, digunakan untuk } \\
\text { memutar atau memilih video-video } \\
\text { yang berhubung-an dengan energi } \\
\text { alternatif sebagai referensi } \\
\text { penggunaan dan pembuatan energi } \\
\text { alternatif agar pengguna } \\
\text { multimedia ini lebih memahami } \\
\text { dalam penggunaan maupun } \\
\text { pembuatan energi alternatif. }\end{array}$ \\
\hline
\end{tabular}

Agar pengguna lebih mudah mengenali tombol-tombol, maka dalam pembuatan tombol energi alternatifditengahnya diberi gambar yang menjadi simbol atau lambang dari energi alternatif yang ada di dalam menu utama. Untuk energi angin dilambangkan dengan gambar kincir angin karena kincir angin adalah alat utama untuk mengolah energi angin. Untukenergi matahari diberikan gambar matahari dan alat pengolah energinya yang dinamakan solar cell. Untuk energi laut digambarkan dengan ombak laut, energi panas bumi disimbolkandengan pabrik pengolah panas bumi dan tanda panah ke atas yang menggambarkan uap panas yang keluar dari perut bumi, energi biogas disimbolkan dengan unsur gas dan apidan energi biofuel menggunakan gambar daun dan kendaraansebagai lambang yang mempunyai makna energi biofuel dapat digunakan pada kendaraan yang bahan bakarnya berbahan nabati atau tumbuh-tumbuhan. Berikut ini adalah gambar pembuatan tombol-tombol energi energi alternatif yang digunakan pada multimedia interaktif pengenalan pengenalan energi alternatif.

Tabel 2. TombolMenu Energi Alternatif

\begin{tabular}{|l|l|l|l|}
\hline No & Gambar & Nama Tombol & \multicolumn{1}{c|}{ Keterangan } \\
\hline 1 & Energi Angin & $\begin{array}{l}\text { Tombol MenuEnergi Angin } \\
\text { berfungsi untuk menampilkan } \\
\text { informasi tentang energi angin dan } \\
\text { gambar contoh penggunaan energi } \\
\text { ini serta kelebihan dan kekurangan } \\
\text { energi angin. }\end{array}$ \\
\hline 2 & Energi Matahari & $\begin{array}{l}\text { Tombol Menu Energi Matahari } \\
\text { digunakan untuk menampilkan } \\
\text { informasi tentang energi matahari } \\
\text { serta contoh penggunaan energi ini, } \\
\text { kelebihan penggunaan energi } \\
\text { matahari dan juga kekurangnnya. }\end{array}$ \\
\hline
\end{tabular}




\begin{tabular}{|c|c|c|c|}
\hline No & Gambar & Nama Tombol & Keterangan \\
\hline 3 & & Energi Laut & $\begin{array}{l}\text { Tombol Menu Energi Laut } \\
\text { digunakan untuk memberikan } \\
\text { keterangan tentang bagaimana } \\
\text { energi laut digunakan sebagai } \\
\text { energi alternatif, gambar contoh } \\
\text { penggunaan energi laut, kelebihan } \\
\text { dan juga kekurangan dari energi } \\
\text { laut. }\end{array}$ \\
\hline 4 & & Energi Panas Bumi & $\begin{array}{l}\text { Tombol Menu Energi Panas Bumi } \\
\text { ini berfungsi untuk menampilkan } \\
\text { keterangan dan pengetahuan } \\
\text { tentang Energi Panas Bumi, } \\
\text { Keunggulan dan kelemahan } \\
\text { penggunaan energi ini. }\end{array}$ \\
\hline 5 & & Energi Biogas & $\begin{array}{l}\text { Tombol Menu Energi Biogas } \\
\text { difungsikan untuk memberikan } \\
\text { pengetahuan dan informasi tentang } \\
\text { energi biogas serta bahan-bahan } \\
\text { yang digunakan untuk energi } \\
\text { alternatif ini, kelebihan penggunaan } \\
\text { dan juga kekurangnnya. }\end{array}$ \\
\hline 6 & & Energi Biofuel & $\begin{array}{l}\text { Tombol Menu Energi Biofuel ini } \\
\text { berfungsi untuk menampilkan } \\
\text { informasi dan pengetahuan tentang } \\
\text { Energi Biofuel, serta } \\
\text { menampilkankeunggulan dan } \\
\text { kelemahan penggunaan energi ini. }\end{array}$ \\
\hline
\end{tabular}

Tampilan awal multimedia menampilkan judul multimedia yang ditulis dalam kalimat ajakan untuk mengenal energi alternatif kemudian pada bagian background ditampilkan kumpulan foto alat-alat untuk mengolah energi alternatif agar user mendapatkan gambaran isi dari multimedia interaktif ini. Berikut adalah gambar dari tampilan awal multimedia.

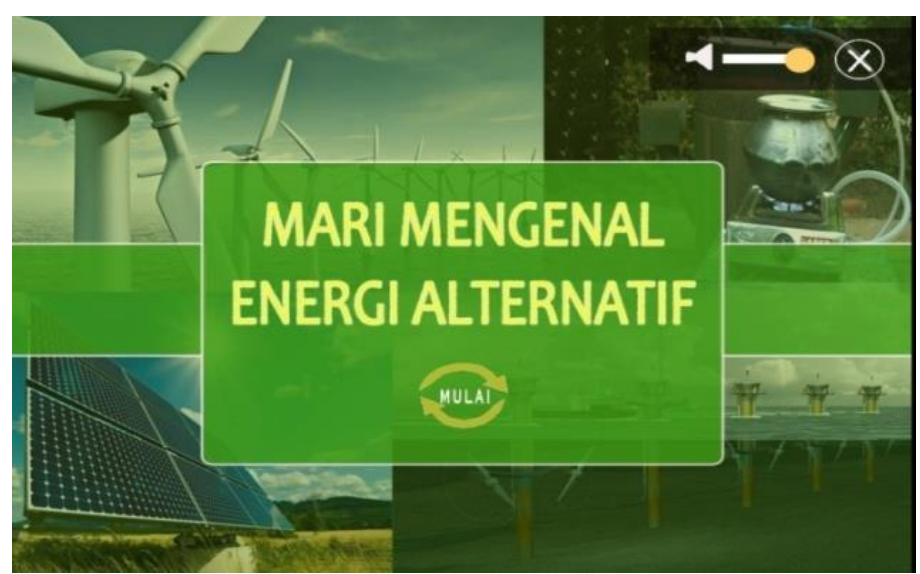

Gambar 5. Tampilan Awal Multimedia 
Pada tampilan utama terdapat tujuh menu jenis energi alternatif, dari tujuh menu jenis energi alternatif ada satu menu yang berisi kumpulan video yang berisi seputar energi alternatif yang dibahas di multimedia interaktif ini. Berikut adalah tampilan menu utama.

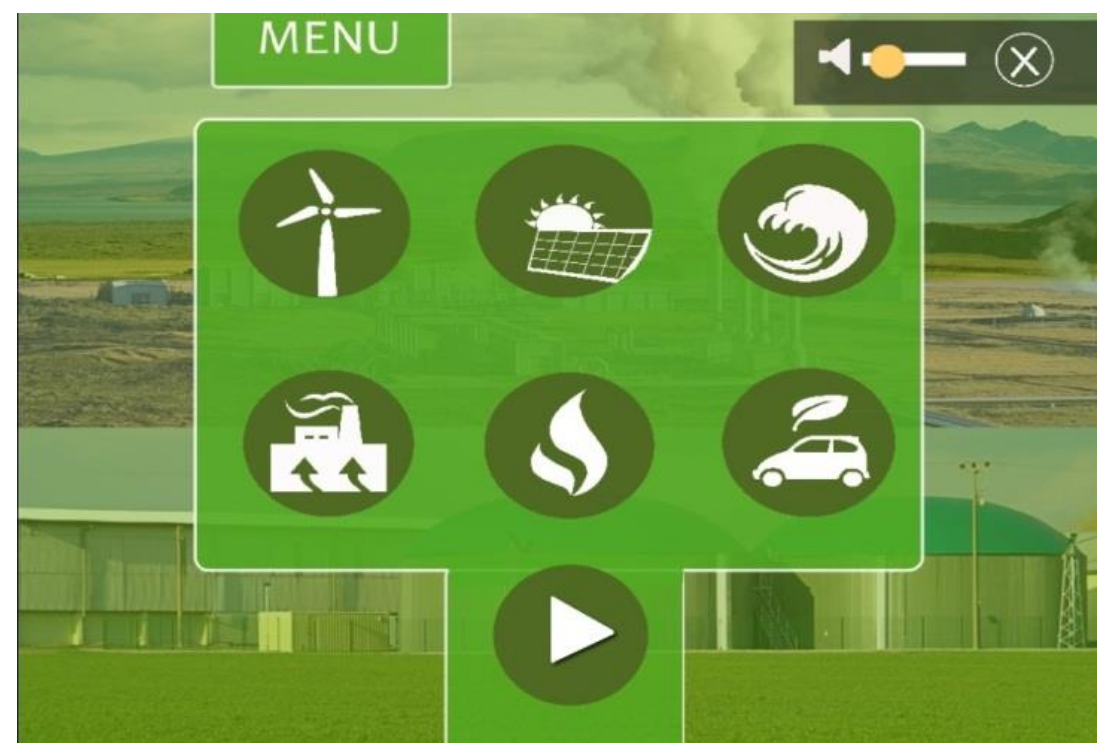

Gambar 6. Tampilan Menu Utama

Tampilan menu energi angin menampilkan gambar dan penjelasan mengenai energi angin pada menu energi angin dan menu jenis energi lainnya ditambahkan tombol home sebagai navigasi kembali ke menu utama berikut tampilan menu energi angin.

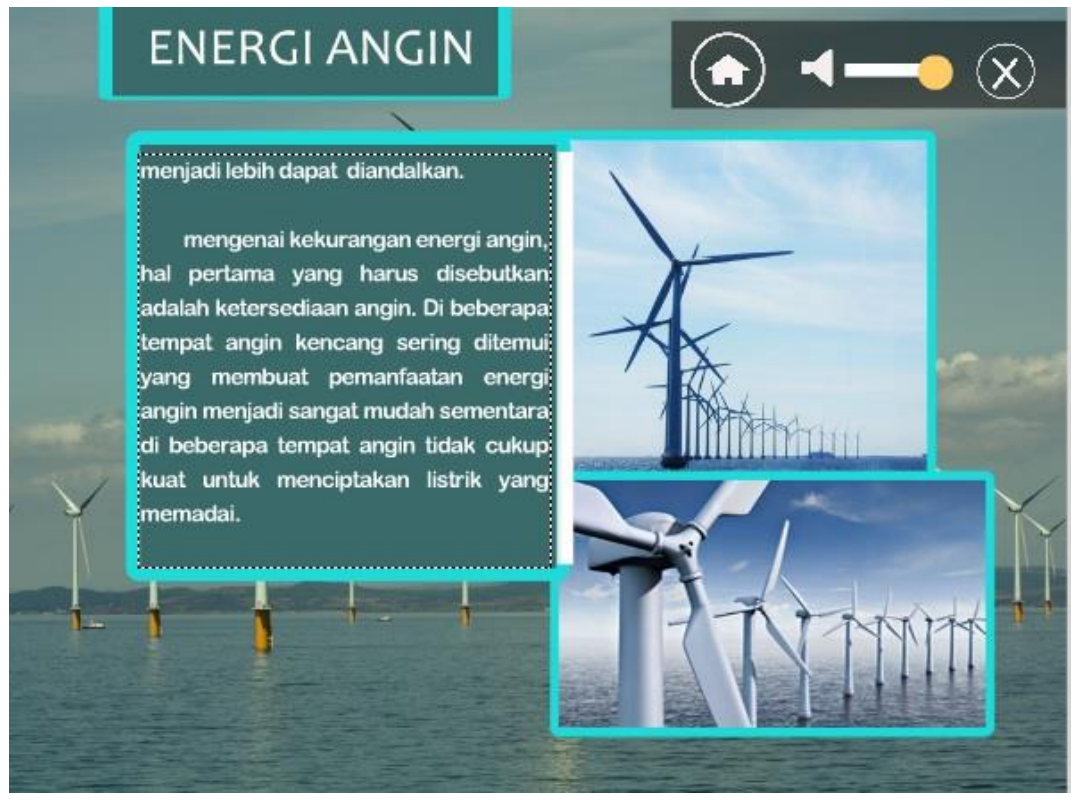

Gambar 7. Tampilan Menu Energi Angin

Tampilan menu energi matahari menampilkan gambar dan terdapat informasi mengenai penjelasan tentang energi alternatif yang berasal dari matahari. Berikut adalah tampilan menu energi matahari 


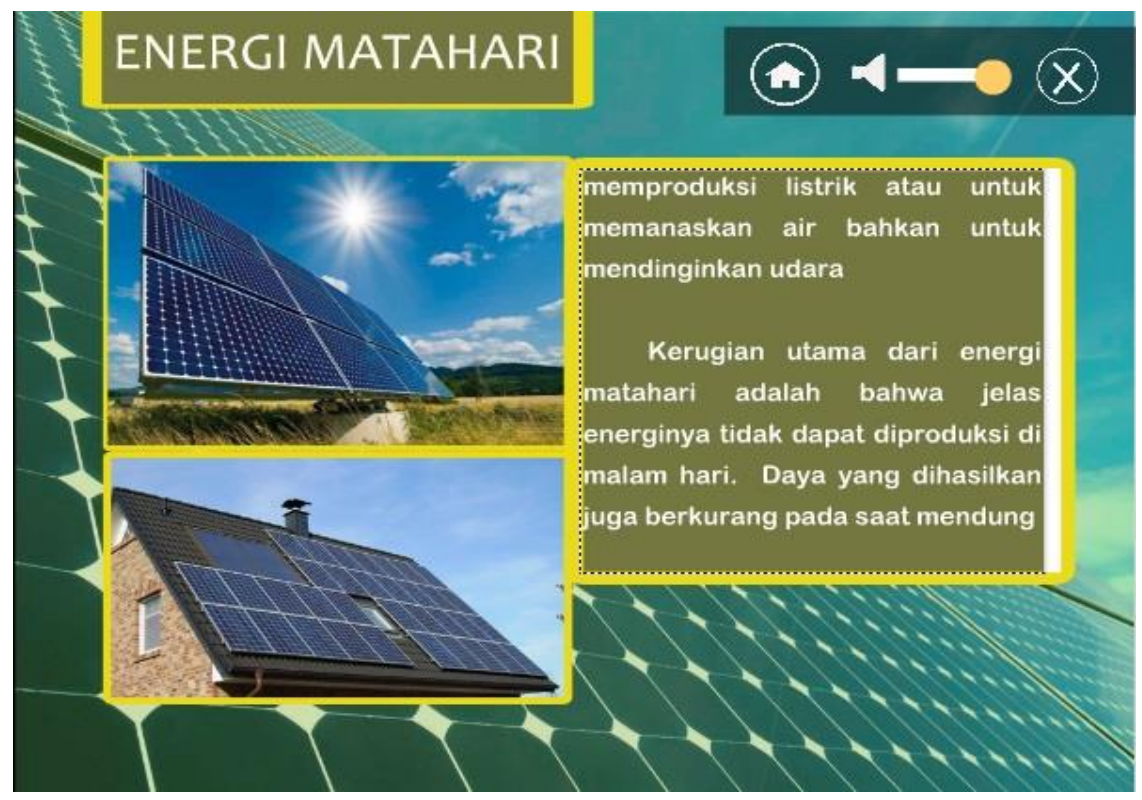

Gambar 8. Tampilan Menu Energi Matahari

Tampilan menu energi panas bumi menampilkan gambar dan informasi mengenai penjelasan tentang energi panas bumi. Berikut adalah gambar tampilan menu energi panas bumi

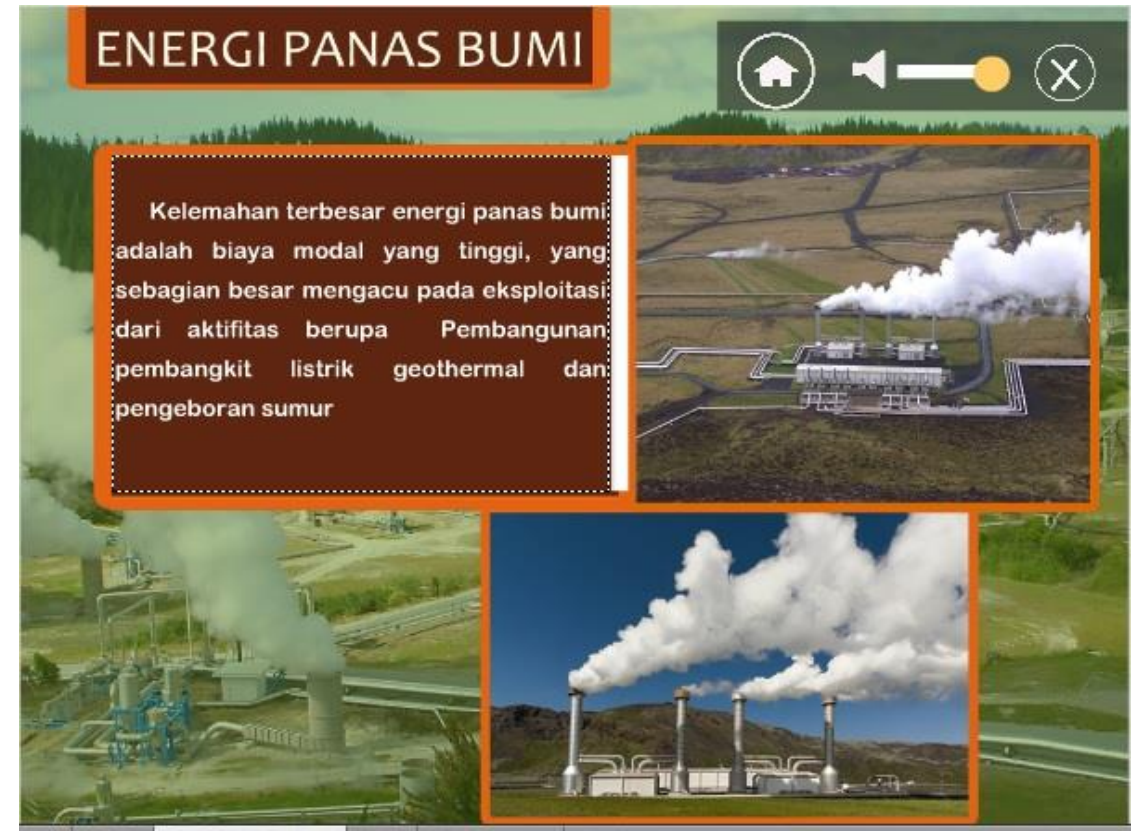

Gambar 9. Tampilan Menu Energi Panas Bumi

Tampilan menu energi laut menampilkan gambar dan informasi mengenai penjelasan tentang energi laut. Berikut adalah gambar tampilan menu energi laut 


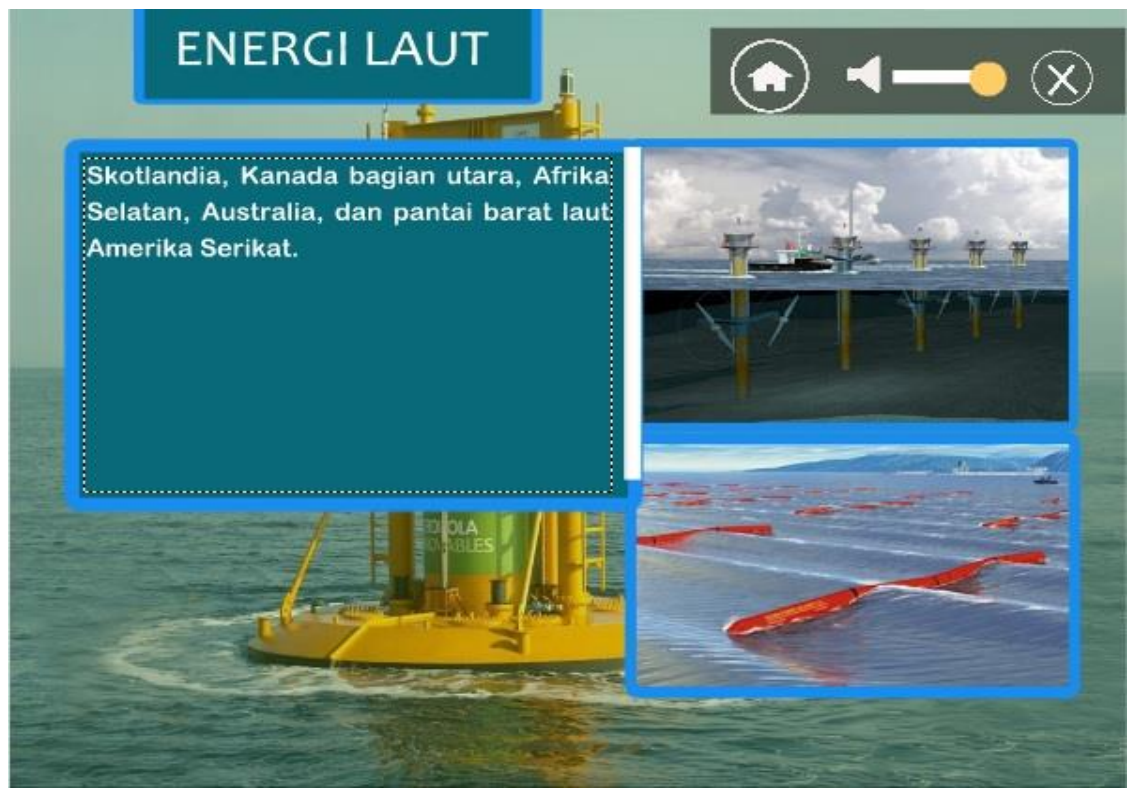

Gambar 10. Tampilan Menu Energi Laut

Tampilan menu energi biogas menampilkan gambar dan informasi mengenai penjelasan tentang energi biogas. Berikut adalah gambar tampilan menu energi biogas

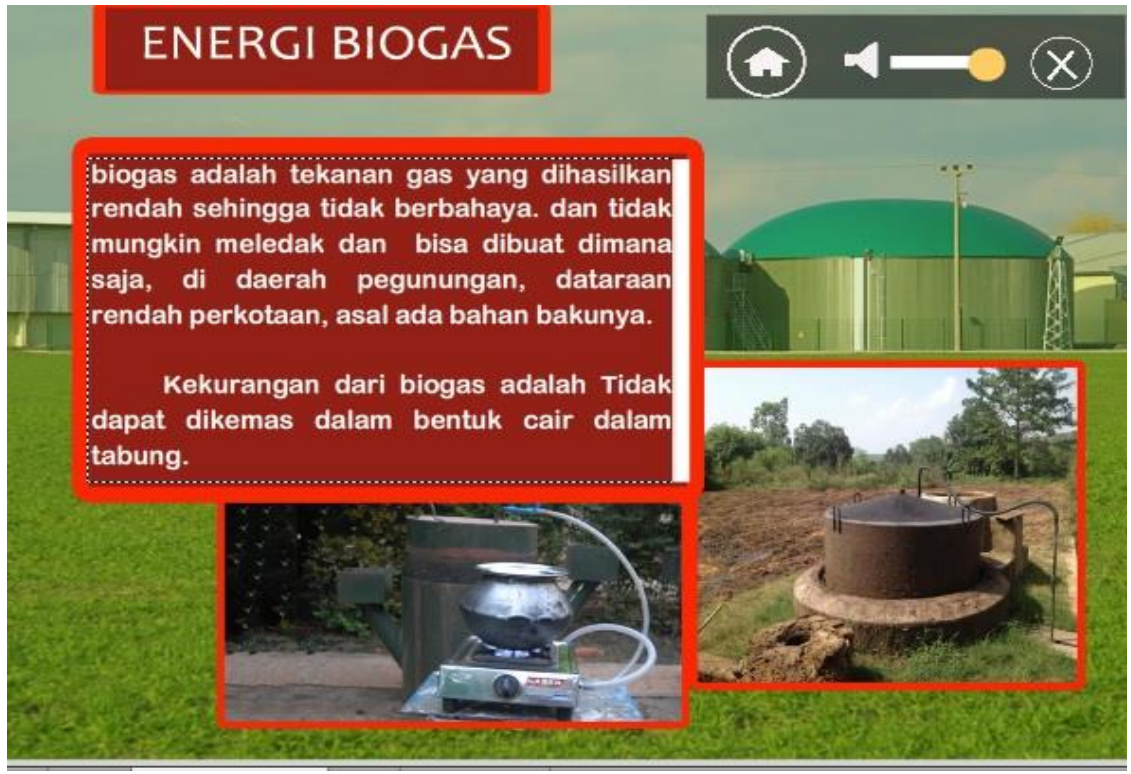

Gambar 11. Tampilan Menu Energi Biogas

Tampilan menu energi biofuel menampilkan gambar dan penjelasan mengenai energi biofuel. Berikut adalah tampilan menu energi biofuel. 


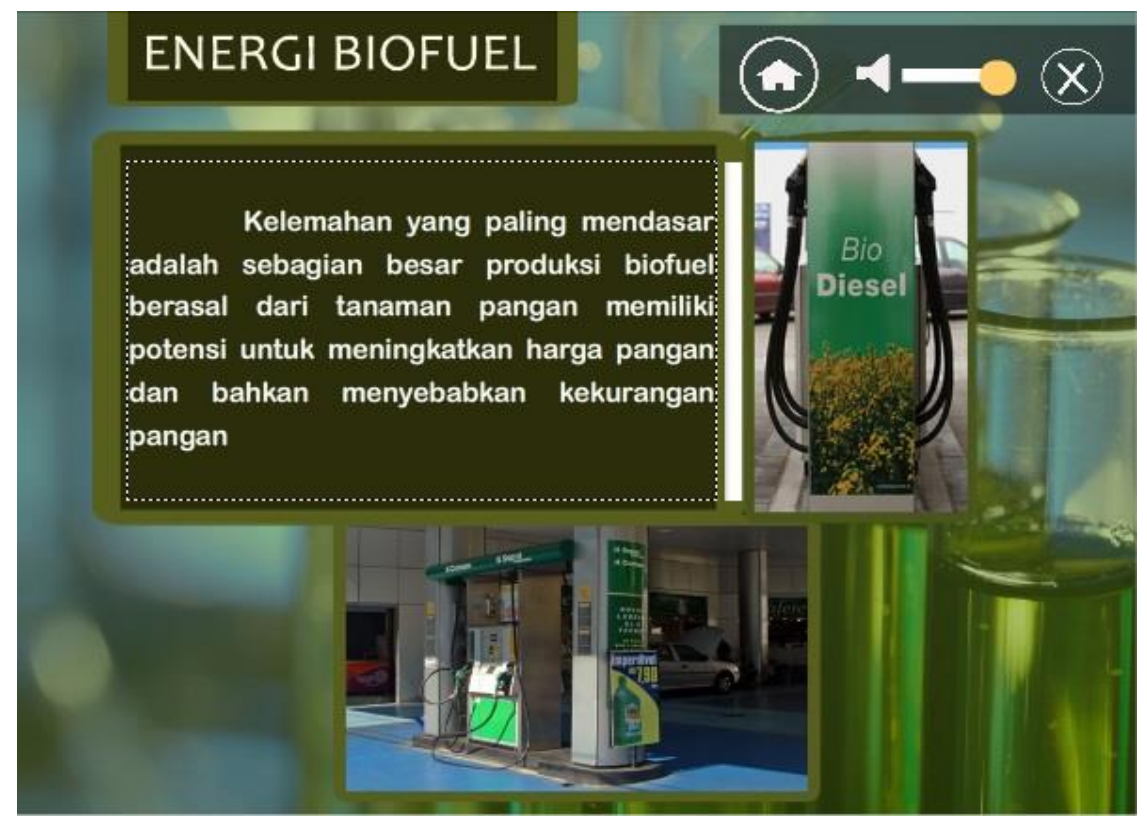

Gambar 12. Tampilan Menu Energi Biofuel

Tampilan menu video menampilkan beberapa video yang berkaitan dengan jenis energi alternatif yang ada dibahas di dalam multimedia interkatif Berikut adalah tampilan menu video

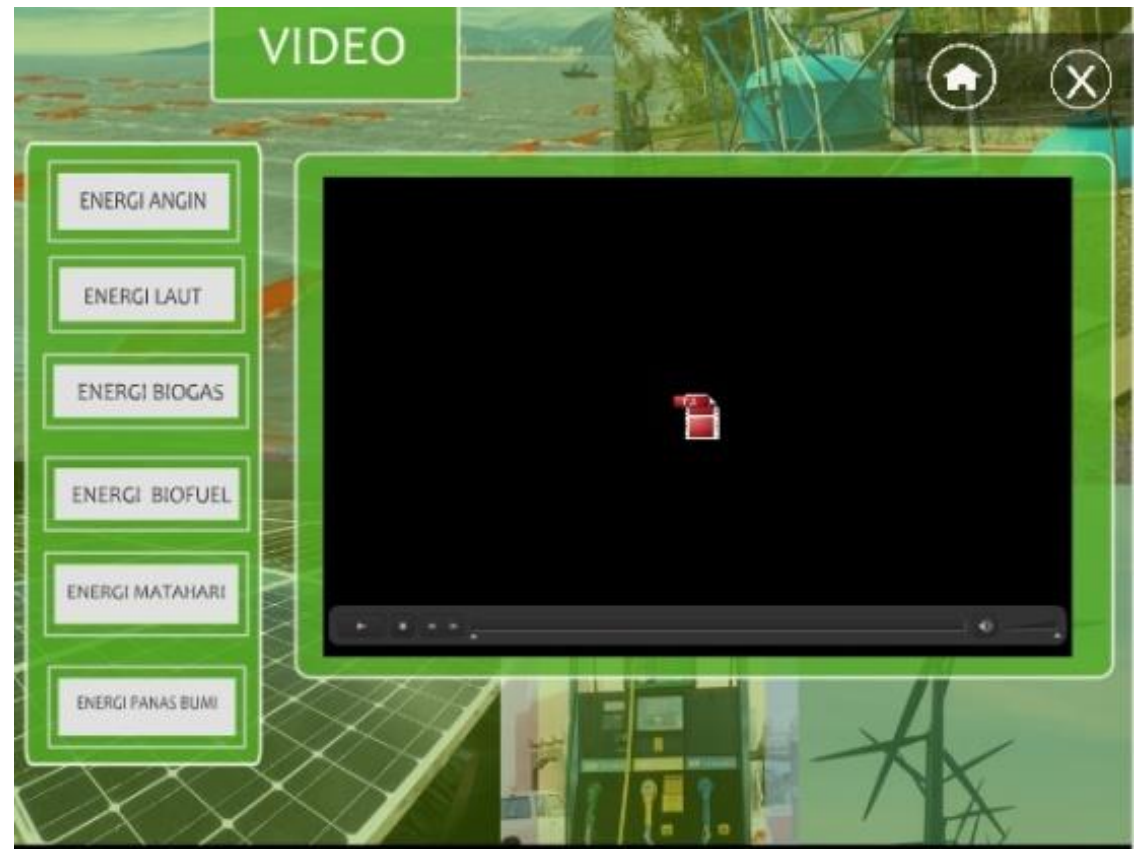

Gambar 13. Tampilan Menu Video

\section{KESIMPULAN}

Multimedia interaktif yang dibuat pada penelitian ini belum mencakup semua jenis energi alternatif yang sudah ada, dikarenakan banyak sumber energi alternatif yang masih dalam tahap pengembangan dan uji coba. Informasi yang ada di dalam multimedia ini lebih ditekankan kepada pengenalan tentang jenis-jenis energi alternatif. Sebagai media yang bersifat interaktif media ini masih memiliki kekurangan pada sisi interaktifitas antara user 
dan media. Berdasarkan hasil kuisioner dapat disimpulkan bahwa jawaban dari 20 responden dengan persentase jawaban ya sebanyak $72.5 \%$ dan persentase jawaban tidak sebanyak 27. 5\% mengindikasikan secara umum multimedia interaktif ini dapat dikatakan baik.

Interaktifitas media perlu ditingkatkan karena hal ini merupakan point penting supaya user tidak cepat bosan dan juga merupakan unsur penting dalam pembuatan aplikasi berbasis multimedia interaktif. Tambakan animasi pada saat opening media atau salah satu objek sehingga media interaktif terlihat lebih menarik bagi pengguna.

\section{DAFTAR PUSTAKA}

Binanto, Iwan. 2010. Multimedia Digital, Dasar Teori Dan Pengembangannya. Yogyakarta: Andi.

Bovee, Courtland. 1987. Cotemporary Advertising, Newyork: McGraw Hill Higher.

Comobe. 2013. Intisari Rahasia Photoshop. Jakarta: Elex Media Komputindo.

Darmaprawira, Sulasmi. 2002. Warna teori dan kreativitas penggunaanya. Bandung: ITB

Effendy, Onong. 1986. Dinamika Komunikasi, Bandung: Remaja Karya.

Flavin, Christopher. 1995. Gelombang Revolusi Energi. Yayasan Obor Indonesia: Jakarta.

Madcoms. 2011. Kupas Tuntas Adobe Flash CS5. Yogyakarta: Andi.

Madcoms. 2011. Adobe Ilustrator CS5 Untuk Pemula. Yogyakarta: Andi.

Nugroho, Hanan. 2012. Energi dalam Perencanaan Pembangunan. IPB: Press Bogor.

Prihandana, Rama. 2008. Energi Hijau: Pilihan Bijak Menuju Negeri Mandiri Energi. Jakarta: Penebar Swadaya.

Purnawati \& Eldandri. 2001 Media Pembelajaran, Jakarta: Grasindo.

Rustan, Surianto. 2008. Layout Dasar Dan Penerapannya. Jakarta: Gramedia Pustaka Utama.

Rustan, Surianto. 2011. Huruf, Font, dan Tipografi. Jakarta: Gramedia Pustaka Utama. Arikunto, Suharsimi. 2003. Prosedur Penelitian, Suatu Praktek. Jakarta: Bina Aksara.

Sanyoto, Sadjiman. 2005. Dasar-Dasar Tata Rupa dan Desain. Yogyakarta, Satria Multimedia.

Supriyono, Rakhmat. 2010. Desain Komunikasi Visual Teori dan Aplikasinya, Yogyakarta: Andi.

Riley, Richard. 2008. Editing Audio dengan Adobe Audition. Jakarta, PC Publishing. 